\begin{tabular}{|c|c|c|c|}
\hline & $\begin{array}{r}\text { Anna } \\
\text { http://wv }\end{array}$ & $\begin{array}{l}\text { Journal } \\
\text { /index.php }\end{array}$ & \multirow{2}{*}{ 2. } \\
\hline & Print ISSN : 2278-9839 & Online ISSN : 2393-9885 & \\
\hline
\end{tabular}

Original article

\title{
In vitro profiling of plants used in Sudanese traditional medicine for antioxidant and anti-breast cancer activities
}

\author{
Mazen Taha, Bushra Parveen*, Bashier Osman, Iman H. Abdoon, Mona S. Mohamed, Wadah J.A. \\ Osman and Sayeed Ahmad \\ Faculty of Pharmacy, University of Khartoum, Khartoum, Sudan \\ *Pharmaceutical Medicine, Department of Pharmacology, School of Pharmaceutical Education and Research, \\ Jamia Hamdard, New Delhi-110062, India \\ **Bioactive Natural Product Laboratory, School of Pharmaceutical Education and Research, Jamia Hamdard, \\ New Delhi-110062, India
}

Received January 30, 2019: Revised March 20, 2019: Accepted March 25, 2019: Published online June 30, 2019

\begin{abstract}
Traditionally, medicinal plants have inhabited an important position in the socio-cultural, spiritual and medicinal domain of rural and tribal lives in Sudan. In the recent years, there is an ever-increasing curiosity in elucidating the role of free radicals in biology, because of their involvement in a diverse range of diseases. Therefore, medicinal plants with antioxidant activity appear to be an intriguing area for research. Hence, the study was aimed to evaluate the antioxidant activity together with anti-breast cancer activity for 14 selected medicinal plants used in Sudanese folkloric medicine. The phytoconstituents of ethanolic extracts were assessed using standard phytochemical screening method. The extracts were then subjected to assess the quantitative antioxidant activity using DPPH radical scavenging and iron chelating assays. MCF7 cell line was used to evaluate the antibreast cancer activity for the most powerful antioxidant extracts. Plant extracts of different concentrations; 5, 12.5, 25, 50 $\mu \mathrm{g} / \mathrm{ml} \mathrm{were} \mathrm{used}$ for the calculation of $\mathrm{IC}_{\mathbf{5 0}}$ values using GRAPH PAD PRISM 5 SOFTWARE. Doxorubicin was used as the standard. All plants under study showed positive results for alkaloids, flavonoids, sterols and carbohydrate. L. inermis, L. camara, H. abyssinica, G. villosa, and R. communis, showed the highest DPPH radical scavenging activity with $\%$ RSA values of $93 \pm 0.01,92 \pm 0.01,74 \pm 0.14,61 \pm 0.04$, and $45 \pm 0.02$, respectively. On the other hand, ethanolic extracts of $T$. foenum-graecum, $C$. decidua, B. oralceae, A. bracteolata, and $R$. communis were found to be the top most extracts in terms of iron chelating ability with percentage iron chelating ability values of $68 \pm 0.03$, $50 \pm 0.01,46 \pm 0.10,44 \pm 0.01$ and $38 \pm 0.02$, respectively. All extracts of the selected plants showed marked cytotoxicity against MCF7 cells compared with reference control drug (Doxorubicin). However, among the top highest extracts showing antioxidant activity, Lawsonia inermis and Aristolochia bracteolata extracts reported the most potent cytotoxic activity with $\mathrm{IC}_{50}$ of $19.1 \mu \mathrm{g} / \mathrm{ml}$.
\end{abstract}

Keywords: Phytochemical screening, antioxidant, antibreast cancer, Sudanese medicinal plants

\section{Introduction}

Oxidative stress represents an imbalance between the production and manifestation of reactive oxygen species (ROS) (Lim and Luderer, 2011). These ROS are capable of attacking and damaging the biological molecules such as DNA, proteins, carbohydrates and lipids (Young and Woodside, 2001). The factors causing oxidative stress may be exogenous such as drugs (Gospodaryov and Lushchak, 2012) or endogenous including different cellular organelles such as mitochondria, peroxisomes and endoplasmic reticulum, where the oxygen consumption is high (Phaniendra et al., 2015).

The recent years have witnessed an upsurge in studying the role of free radicals in biology, because of their crucial role in various

\footnotetext{
Author for correspondence: Dr. Sayeed Ahmad

In Charge: Bioactive Natural Product Laboratory and

Associate Professor, Department of Pharmacognosy and Phytochemistry, School of Pharmaceutical Education and Research, Jamia Hamdard, New Delhi-110062, India

E-mail: sahmad_jh@yahoo.co.in

Tel.: +91-9891374647
}

Copyright () 2019 Ukaaz Publications. All rights reserved.

Email: ukaaz@yahoo.com; Website: www.ukaazpublications.com physiological conditions as well as their involvement in a diverse range of diseases (Phaniendra et al., 2015) like ischemia-reperfusion injury (Omar et al., 1991), coronary arteriosclerosis (Jackson et al., 1993), diabetes mellitus (Sugawara et al., 1992), neuro degenerative diseases (Simonian and Coyle, 1996), ageing process (Lim and Luderer, 2011) and carcinogenesis (Smith, 1995). ROS are thought to be implicated in cancer pathogenesis through two possible mechanisms: gene mutations and effects on signal transduction and transcription factors (Klatt, 1999; Reynaert et al., 2006). The complex antioxidant defense system of the human body consists of exogenous dietary intake of antioxidants, as well as the endogenous production of antioxidant compounds, such as glutathione (Clarkson and Thompson, 2000), that may work either alone, or in association with each other. For example, the combination of vitamin $\mathrm{C}$ and vitamin $\mathrm{E}$ suppress the formation of hydroperoxide, while metal complex antioxidant such as penicillamine inhibits free radical formation in lipid peroxidation (Feher et al., 1987).

Cancer constitutes a major public health problem in many parts of the world (Hanahan and Weinberg, 2000). It is the second most 
common cause of death in the United States, after cardiovascular diseases (Anonyms, 2015) and the third leading cause of death after malaria and viral pneumonia in Sudanese hospital (Anonyms, 2005). In Sudan, like other parts of the world, incidence of cancer has increased phenomenally over the last five decades (Mohammed et al., 2013) and breast cancer is the most common type affecting both sex (Ferlay et al., 2015). The cost of cancer treatment is humongous, as compared to the success rate of chemotherapy, which is very low. The herbal treatment for breast and prostate cancer showed an $85 \%$ success rate at 4 years as compared to the traditional chemotherapy having $2.1 \%$ success rate at 5 years (Morgan et al., 2004).

Over its long history, the Sudan has witnessed blend of many cultures, Pharonic, Christian and Islamic along with the local indigenous cultures. With this unique history and vast variety of climate and flora, traditional medicine together with medicinal plants became an important part of the cultural heritage of the Sudan (Musa et al., 2011).

Medicinal plants, with antioxidant activity containing flavonoids, phenolic acids (Milivojeviæ et al., 2011), tannins, anthocyanins (Dyduch-Siemiñska et al., 2015), coumarins, xanthones (Kattappagari et al., 2015), terpenoids (Tringali, 2001), phenylpropanoids and phenylpropanoid derivatives (Nagababu and Lakshmaiah, 1992) are the major phytoconstituents (Fabricant and Farnsworth, 2001; Rafieian-Kopaeiet al., 2014; Shirzad et al., 2011) presenting potential candidature for drug development. In the present work, fundamental initial screening of fourteen selected Sudanese medicinal plants has been carried out for their antioxidant and anti-breast cancer activities in vitro.

\section{Materials and Methods}

\subsection{Plant materials}

Different parts of fourteen Sudanese medicinal plants (Table 1) were collected in the period, July-December, 2013 from different parts of Sudan. The collected plant parts were authenticated at the herbarium of the Aromatic and Medicinal Plants Research Institute. Voucher specimens were deposited there for future reference.

Table 1: Sudanese medicinal plants

\begin{tabular}{|l|l|l|}
\hline Botanical name & Local name & Part used \\
\hline Aristolochia bracteolata & AM-Galagil & Roots \\
Brassica oleracea & Kroomb & Leaves \\
Capparis decidua & Tondoob & Arial parts \\
Chamomilla recutita & Al-babonj & Flowers \\
Cymbopogon citratus & HashishaAllymon & Arial parts \\
Grewia villosa Willd & Tickoo & Leaves \\
Hydnora abyssinica & Tratous & Rhizome \\
Kigelia Africana & Am-Shotor & Fruits \\
Lantana camara & Lantana & Roses \\
Lawsonia inermis & Henna & Leaves \\
Moringa oleifera & Moringa & Roots \\
Nigella sativa & Habaalsoda & Seeds \\
Ricinus communis & Kheriwa & Leaves \\
Trigonella foenum-graecum & Helba & Seeds \\
\hline
\end{tabular}

\subsection{Extraction procedure}

The samples were air-dried for two weeks and powdered by a mechanical grinder. $100 \mathrm{~g}$ of each plant powder was extracted excessively with $75 \%$ ethanol using Soxhlet extractor for 3 hours. The plant extracts were filtered through Whatman filter paper number 2, and concentrated under reduced pressure and then kept in refrigerator for further investigation.

\subsection{Qualitative analysis of phytoconstituents}

A portion of the concentrated extract was used for the screening tests using standard method (Ayeni and Yahaya, 2010).

\subsubsection{Test for carbohydrates / reducing sugars}

The dried powdered plant (5 mg) was boiled with $100 \mathrm{ml}$ of distilled water and the resultant aqueous solution was filtered through a cloth of muslin and tested as follows:

- $2 \mathrm{ml}$ aliquot of the filtrate was mixed with $0.2 \mathrm{ml}$ of ethanolicanaphthol (20\%), followed by $2 \mathrm{ml}$ of sulphuric acid (98\%), poured carefully on the side of the test tube to form two layers. A violet zone at the junction of the two layers indicated the presence of carbohydrates (Molish's test).

- $5 \mathrm{ml}$ from the filtrate was heated in water bath with $5 \mathrm{ml}$ Fehling's solution for $5 \mathrm{~min}$, a red precipitate indicated the presence of reducing sugars (Fehling test).

\subsubsection{Test for tannins}

One gram from the dried plant powder was extracted with aqueous ethanol (50\%). $5 \mathrm{ml}$ of the aqueous extracts of each plant were added to $0.5 \mathrm{~g}$ of $\mathrm{NaH}_{2} \mathrm{PO}_{4}$, and warmed and then cooled and filtered. To the filtrate, $2 \mathrm{ml}$ of $2 \%$ solution of phenazonewas added, resulting in the formation of a precipitate or turbidity thereby, indicating the presence of tannins.

\subsubsection{Tests for alkaloids and / or nitrogenous bases}

The powdered plant $(10 \mathrm{mg})$ was extracted with acidified water and the acidic filtrate was rendered alkaline by the addition of ammonium hydroxide solution. The mixture was extracted with chloroform and the extract was evaporated to dryness and the residue was dissolved in $2 \mathrm{ml}$ of dilute $\mathrm{HCL}$ and tested with the following reagents: Mayer's, modified Dragendorffs and iodoplatinate modified reagent. A white or orange precipitate or violet colour apperared, respectively, with the reagents, indicating the presence of alkaloids and / or nitrogenous bases.

\subsubsection{Test for flavonoids}

Around $1.0 \mathrm{ml}$ of $10 \%$ ethanolic extract of each plant was treated with $0.5 \mathrm{ml}$ of $10 \%$ hydrochloric acid, then magnesium metal strips were added. A red colour developed indicating the presence of flavonoids.

\subsubsection{Test for saponins}

The dried plant powder $(1.0 \mathrm{gm})$ was boiled in $10 \mathrm{ml}$ water for a few minutes, filtered and shaked. A persistent froth indicated the presence of saponins (Froth test).

\subsubsection{Test for unsaturated sterols and/or triterpenes}

The dried powdered plant $(1.0 \mathrm{~g})$ was extracted with few millilitres of ethanol, filtered and evaporated to dryness then the residue was dissolved in distilled water. Acetic anhydride $(1.0 \mathrm{ml})$ and concentrated sulphuric acid $(2.0 \mathrm{ml})$ were added along the side of the tube. A reddish violet colour at the junction of the two layers 
indicated the presence of unsaturated sterols and/or triterpenes (Liebermann-burchard's test).

\subsubsection{Test for coumarins}

A small amount of moistened plant sample was placed in a test tube and covered with filter paper moistened with dilute sodium hydroxide solution. The tube was then placed in boiling water bath for several minutes. The paper was removed and exposed to ultraviolet light. Appearance of yellow to green colour within a few minutes indicates the presence of coumarins.

\subsubsection{Test for cardiac-glycoside}

One gram of the powdered sample was boiled with $10 \mathrm{ml}$ of $70 \%$ alcohol for $5 \mathrm{~min}$ on a water bath and filtered. The cooled filtrate was diluted with equal volume of distilled water and a few drops of lead acetate was added and shaken thoroughly. This was allowed to stand for some minutes and then filtered. The filtrate was extracted with 2 volumes of chloroform and the combined extracts were concentrated to form a residue that was used for following test:

- $0.5 \mathrm{gm}$ of the residue was dissolved in $5.0 \mathrm{ml}$ pyridine, followed by addition of 2 drops of $2 \%$ sodium nitro-prusside and 2 drops of $20 \%$ sodium hydroxide. A deep red color faded to brown indicates presence of cardenolide (Legal's test).

\subsubsection{Test for anthracenoside}

Three $\mathrm{ml}$ of extract was treated with dilute sulfuric acid then boiled and filtered. Equal volume of chloroform was added to the cold filtrate and shaked for some time. The organic layer is separated and treated with $1-2 \mathrm{ml}$ of dilute ammonia $(25 \%)$. Appearance of pinkish color in ammonia layer indicated anthraquinone glycoside (Borntrager's test).

\subsection{Quantitative determination of the antioxidant activity}

\subsubsection{DPPH radical scavenging assay}

The test was performed according to the method prescribed by Shimada. et al. (1992) with some modifications. In a 96-well plate, $10 \mu \mathrm{l}$ from a $5 \mathrm{mg} / \mathrm{ml}$ of each test extract, dissolved in neat dimethyl sulfoxide (DMSO) was allowed to react with $90 \mu 1(300 \mu \mathrm{M})$ ethanolic solution of DPPH for half an hour at $37^{\circ} \mathrm{C}$. After incubation, the absorbance of the reaction mixture was measured at $517 \mathrm{~nm}$ against a blank solution of DPPH in DMSO using multi-plate reader spectrophotometer. Propylgalate was used as a standard drug at a concentration of $0.5 \mathrm{mM}$. The assay was performed in triplicate and percentage radical scavenging activity (\% RSA) of each test sample was calculated using the following formula:

$$
\% \operatorname{RSA}=\left[\left(\mathrm{A}_{\mathrm{c}}-\mathrm{A}_{\mathrm{t}}\right) / \mathrm{Ac}\right] \times 100
$$

where, RSA is radical scavenging activity present; $A_{c}$ is the absorbance of the control and $\mathrm{A}_{\mathrm{t}}$ is absorbance of the test extract at $517 \mathrm{~nm}$.

\subsubsection{Iron chelating activity assay}

The assay was accomplished according to the modified method of Dinis et al. (1994). The antioxidant property of the plant extract is demonstrated by their ability to chelate ferrous and disturbing the complex formation between ferrozine and $\mathrm{Fe}^{+2}$ which causes a decrease in the red color intensity of the ferrozine - $\mathrm{Fe}^{+2}$ complex. In a 96-well plate, $10 \mu 1$ from a $5 \mathrm{mg} / \mathrm{ml}$, of each test extract, dissolved in ethanol was mixed and allowed to react with Ferrous Sulphate $(30 \mu 1,0.0625 \mathrm{mM}$ in DMSO) for $5 \mathrm{~min}$ at room temperature. The reaction was initiated by adding ferrozine $(60 \mu 1$, $0.5 \mathrm{mM}$ in DMSO). The reaction mixture was mixed thoroughly and left in dark at room temperature for another $10 \mathrm{~min}$. The absorbance of the solution was measured spectrohotometrically at $562 \mathrm{~nm}$. Ethylene diamine tetra-acetate (EDTA, $0.5 \mathrm{mM}$ ) was used as standard and DMSO as control. The assay was performed in triplicates and the percentage inhibition of ferrozine- $\mathrm{Fe}^{+2}$ Complex was calculated using the following formula:

Ferrous ion-chelating ability $(\%)=[($ Abs control-Abs sample $) /$ Abs control] $\times 100$.

\subsection{Screening anti-breast cancer activity}

Cell line (MCF7) was obtained from the American Type Culture Collection (ATCC, Minnesota, U.S.A.), and the activity was performed as per the method by Skehen et al. (1990).

\subsubsection{Cell culture}

MCF7 cells were grown at $37^{\circ} \mathrm{C}$ in a humidified atmosphere containing 5\% $\mathrm{CO}_{2}$ (Heraeus BBD 6220 incubator) and cultured in RPMI 1640 supplemented with $10 \%$ fetal bovine serum (FBS), and $1 \%$ penicillin/streptomycin. For experiments, frozen cells in cryotubes were kept in liquid nitrogen at $-180^{\circ} \mathrm{C}$ and thawed in a water bath at $37^{\circ} \mathrm{C}$. After thawing, the contents were supplied to a $5 \mathrm{ml}$ culture medium in a $50 \mathrm{ml}$ sterile falcon tubes. Cells were then incubated at $37^{\circ} \mathrm{C}$ for $2 \mathrm{~h}$, and centrifuged at $1200 \mathrm{rpm}$ for $10 \mathrm{~min}$. Afterwards, the cell pellet was suspended in warm culture medium and seeded in $5 \mathrm{ml}$ supplemented medium in T25 nunclon sterile tissue culture flask. Thereafter, cell suspension was incubated at $37^{\circ} \mathrm{C}$ in a humidified atmosphere containing $5 \% \mathrm{CO}_{2}$. Medium was changed every 2-3 days and continued to incubate the cells in same conditions until a confluent growth. Cells were then washed twice in phosphate buffered saline (PBS) and subsequently incubated with trypsin-EDTA solution for $2 \mathrm{~min}$. at $37^{\circ} \mathrm{C}$. After cells had dislodged from the surface, the culture medium was added, and centrifuged at $800 \times \mathrm{g}$ for $5 \mathrm{~min}$ (Heraeus Megafuge 1.0, rotor 7570F). Then, the cell pellets were re-suspended in warm culture medium, diluted and transferred to sterile culture flasks. Cell numbers were determined by using Neubauer chamber. The amount of dead cells were determined by Trypan blue exclusion. For longterm storage, the cells were treated as follows:

After trypsinization, cells were pelleted ( $5 \mathrm{~min}$ at $400 \times \mathrm{g}$ ), diluted in freezing medium (growth medium with $20 \%$ FBS supplemented with $10 \%$ DMSO) and stored in sterile cryotubes (Nunc). The cryotubes were gradually cooled down from $0^{\circ} \mathrm{C}$ to $-80^{\circ} \mathrm{C}$ and finally, stored in liquid nitrogen $\left(-180^{\circ} \mathrm{C}\right)$ till use.

\subsubsection{Determination anti-breast cancer activity of the plants understudy}

The plant extract was prepared in di-methyl sulfoxide (DMSO). Different concentrations of the plants extract were used; $5,12.5$, $25,50 \mu \mathrm{g} / \mathrm{ml}$. For determination of cytotoxicity, cells were seeded into a 96-well microtiter plates at concentration of $3 \times 10^{3}$ cell/well in a $150 \mu \mathrm{l}$ fresh medium and left for $24 \mathrm{~h}$ to attach to the plates. Then, different concentrations of plants extract as well as doxorubicin (positive control) were added, each in triplicate. The 
plates were incubated at $37^{\circ} \mathrm{C}$ in a humidified atmosphere containing $5 \% \mathrm{CO}_{2}$ for $48 \mathrm{~h}$. Afterwards, the cells were fixed with $50 \mu \mathrm{l}$ cold trichloroacetic acid $\left(10 \%\right.$ final concentration) for $1 \mathrm{~h}$ at $4{ }^{\circ} \mathrm{C}$. Thereafter, the plates were washed with distilled water and stained with $50 \mu 10.4 \%$ sulphorhodamine-B (SRB), dissolved in $1 \%$ acetic acid for $30 \mathrm{~min}$ at room temperature. Plates were then washed with $1 \%$ acetic acid and air dried. Finally, the dye was solubilized by the addition of $100 \mu \mathrm{l} /$ well of $10 \mathrm{M}$ tris base ( $\mathrm{pH}$ 10.5) and the optical density (O.D.) of each well was measured spectrohoto metrically at $570 \mathrm{~nm}$ with an ELISA microplate reader (Skehan et al., 1990). The mean background absorbance were automatically subtracted and mean values for each drug concentration was calculated. The experiment was repeated 3 times. The percentage of cell survival was measured as follows:

Surviving fraction $=$ O.D. $($ treated cells $) /$ O.D. $($ control cells $)$

\subsection{Statistical analysis}

All data are presented as Mean \pm standard deviation. The $\mathrm{IC}_{50}$ values (the concentrations of the plant extract and the drug (doxorubicin) required to produce 50\% inhibition of cell growth) were calculated by using GRAPH PAD PRISM 5 SOFTWARE.

\section{Results}

\subsection{Phytochemicals screening}

All plants under study showed positive results for alkaloids, flavonoids, sterols and carbohydrate whereas; saponins were only detected in Trigonella foenum-graecum, Aristolochia bracteolata and Nigella sativa. On other hand, cardiac glycosides were detected in Capparis decidua and Kigelia africana. Coumarin was detected only in Kigelia africana while anthracenes were not detected in any of the extracts under study (Table 2).

Table 2: Qualitative analysis of phytoconstituents

\begin{tabular}{|l|c|c|c|c|c|c|c|c|c|c|}
\hline Plant & Sap. & Alk. & Flav. & Ster & Carbo. & R.sug. & Tann & Coum & C.Glyco & Anthra \\
\hline Lawsoniainermis & - & + & + & + & + & - & + & - & - & - \\
Capparis decidua & - & + & + & + & + & - & + & - & + & - \\
Hydnoraabyssinica & - & + & + & + & + & + & + & - & - & - \\
Cymbopogoncitratus & - & + & + & + & + & + & - & - & - & - \\
Grewiavillosa & - & + & + & + & + & + & - & - & - & - \\
Kigeliaafricana & - & + & + & + & + & - & - & + & + & - \\
Brassica oleracea & - & + & + & + & + & - & - & - & - & - \\
Trigonellafoenum-graecum & + & + & + & + & + & + & + & - & - & - \\
Lantana camara & - & + & + & + & + & + & + & - & - & - \\
Aristolochiabracteolata & + & + & + & + & + & - & - & - & - & - \\
Nigella sativa & + & + & + & + & + & - & + & - & - & - \\
Ricinuscommunis & - & + & + & + & + & + & - & - & - & - \\
Moringaoleifera & - & + & + & + & + & - & - & - & - \\
Chamomillarecutita & - & + & + & + & + & - & + & - & - & - \\
\hline
\end{tabular}

Saponins (Sap.), Alkaloids (Alk.), Flavonoids (Flav.), Sterols (Ster.), Carbohydrate (Carbo.), Reducing sugers (R.sug), Tannins (Tann.), Coumarins (Coum.), Cardiac Glycoside (C.Glyco.), Anthracene (Anthra.),present (+), absent (-).

\subsection{Quantitative determination of the antioxidant activity}

Ethanolic extracts from L. inermis, L. camara, H. abyssinica, $G$. villosa, and $R$. communis, reported highest DPPH scavenging activity with \% RSA values of $93 \pm 0.01,92 \pm 0.01,74 \pm 0.14,61 \pm 0.04$, and $45 \pm 0.02$, respectively. Whereas, the highest iron chelating activity was found in the following extracts:

T. foenum-graecum, C. decidua, B. oralceae, A. bracteolata, and $R$. communis, with $\%$ iron chelating ability values of $68 \pm 0.03,50 \pm$ $0.01,46 \pm 0.10,44 \pm 0.01$ and $38 \pm 0.02$, respectively (Table 3 ).

\subsection{Anti-breast cancer activity for plants with higher antioxidant activity}

The plant extracts showing highest antioxidant activity in both the assays were subjected to in vitro testing of cytotoxicity against MCF7 cells. All the extracts tested showed marked cytotoxicity against MCF7 cells as compared with reference to control drug
(Doxorubicin). Lawsonia inermis and Aristolochia bracteolata extracts were reported to possess the most potent cytotoxic activity with IC $_{50}$ of $19.1 \mu \mathrm{g} / \mathrm{ml}$ (Table 4) and (Figure1).

\section{Discussion}

Chemically derived drugs have been developed for cancer treatments. However, the current chemotherapeutic agents have limitations due to their toxic effects on non-targeted cells, resulting in adverse consequences (Seca and Pinto, 2018). Therefore, there is a demand for alternative treatments with plant-derived anticancer agents with less toxicity to normal cells. In addition, in the recent past, interest has increased largely in finding natural antioxidants to replace synthetic antioxidants in foods or medicinal products due to their adverse reaction such as carcinogenicity. The antioxidant activity of herbal plants is said to be due to the presence of phytoconstituents, such as phenols and flavonoids. The polyphenolic compounds are said to have chemopreventive and suppressive activities against cancer cells by inhibiting many metabolic enzymes involved in the activation of potential carcinogens or arresting the cell cycle (Sylvie et al., 2014). 
Table 3: Free radical (DPPH) scavenging activity and iron chelating ability of the 14 plant extracts

\begin{tabular}{|l|c|c|}
\hline Plant ethanol extracts & $\begin{array}{c}\text { \% Radical } \\
\text { scavenging } \\
\text { activity } \\
\text { (RSA) } \pm \text { SD }\end{array}$ & $\begin{array}{c}\text { \% Iron } \\
\text { chelating } \\
\text { ability } \pm \text { SD }\end{array}$ \\
\hline Aristolochia bracteolate & $18 \pm 0.02$ & $44 \pm 0.01$ \\
Brassica oleracea & $14 \pm 0.01$ & $46 \pm 0.01$ \\
Capparis decidua & $08 \pm 0.03$ & $50 \pm 0.01$ \\
Chamomillarecutita & $38 \pm 0.04$ & $29 \pm 0.01$ \\
Cymbopogoncitratus & $30 \pm 0.02$ & $35 \pm 0.02$ \\
Grewiavillosa & $61 \pm 0.04$ & $14 \pm 0.02$ \\
Hydnoraabyssinica & $74 \pm 0.14$ & $22 \pm 0.03$ \\
Kigelia Africana & $26 \pm 0.02$ & $34 \pm 0.04$ \\
Lantana camara & $92 \pm 0.01$ & $27 \pm 0.01$ \\
Lawsoniainermis & $93 \pm 0.01$ & $32 \pm 0.02$ \\
Moringaoleifera & $35 \pm 0.01$ & $24 \pm 0.01$ \\
Nigella sativa & $07 \pm 0.03$ & $16 \pm 0.01$ \\
Ricinuscommunis & $45 \pm 0.02$ & $38 \pm 0.01$ \\
Trigonellafoenum-graecum & $0.8 \pm 0.01$ & $68 \pm 0.03$ \\
\hline
\end{tabular}

Standard propylgalate $=92 \pm 0.01 ;$ EDTA $=90 \pm .01$

Table 4: $\mathrm{IC}_{50}$ in $\mu \mathrm{g} / \mathrm{ml}$ for ethanolic extract of selected plants

\begin{tabular}{|l|c|}
\hline Plant ethanolic extract & $\mathbf{I C}_{50}(\boldsymbol{\mu g} / \mathbf{m l})$ \\
\hline Aristolochia bracteolate & 19.1 \\
Brassica oleracea & 21.7 \\
Capparis decidua & 20.3 \\
Cymbopogoncitratus & 25.5 \\
Grewiavillosa & 21.5 \\
Hydnoraabyssinica & 35.5 \\
Lantana camara & 20.5 \\
Lawsoniainermis & 19.1 \\
Trigonellafoenum-graecum & 20.5 \\
Doxorubicin (positive control) & 4.2 \\
\hline
\end{tabular}

In the present study, fourteen Sudanese plants were extracted and evaluated for their antioxidant and anti-breast cancer activities. The antioxidant activity of the plants extracts was evaluated based on their ability to trap DPPH radical and ability to chelate ferrous. $L$. inermis have shown the strongest reducing antioxidant capacity and free radical scavenging ability using DPPH method and iron chelating assay; and these results are almost in agreement with its flavonoids content. Consequently, the antioxidant activity of this plant might be relatedits phenolic content, as also reported in previous studies (Hsouna et al., 2011; Guha et al., 2011; Kumar et al., 2014). L. inermis also exhibited anti-breast cancer activity, suggesting that the free radical scavenging activity might contribute significantly to the anti-breast cancer activity. Several alkaloids isolated from natural herbs exhibit anticancer effects on various types of cancers both in vitro and in vivo (Iqbal et al., 2017). Alkaloids showed diversity in their mechanism of anticancer effect by modulating multiple signaling pathways, resulting in inhibition of glutathione (GSH), topoisomerase enzymes, extra cellular signal- regulated kinase (ERK) and mitogen-activated protein kinase phosphatase 1 (MKP-1) (Lu et al., 2012). Our study reported presence of alkaloids in L. inermis, which may contribute to the anti-breast cancer activity of this plant.
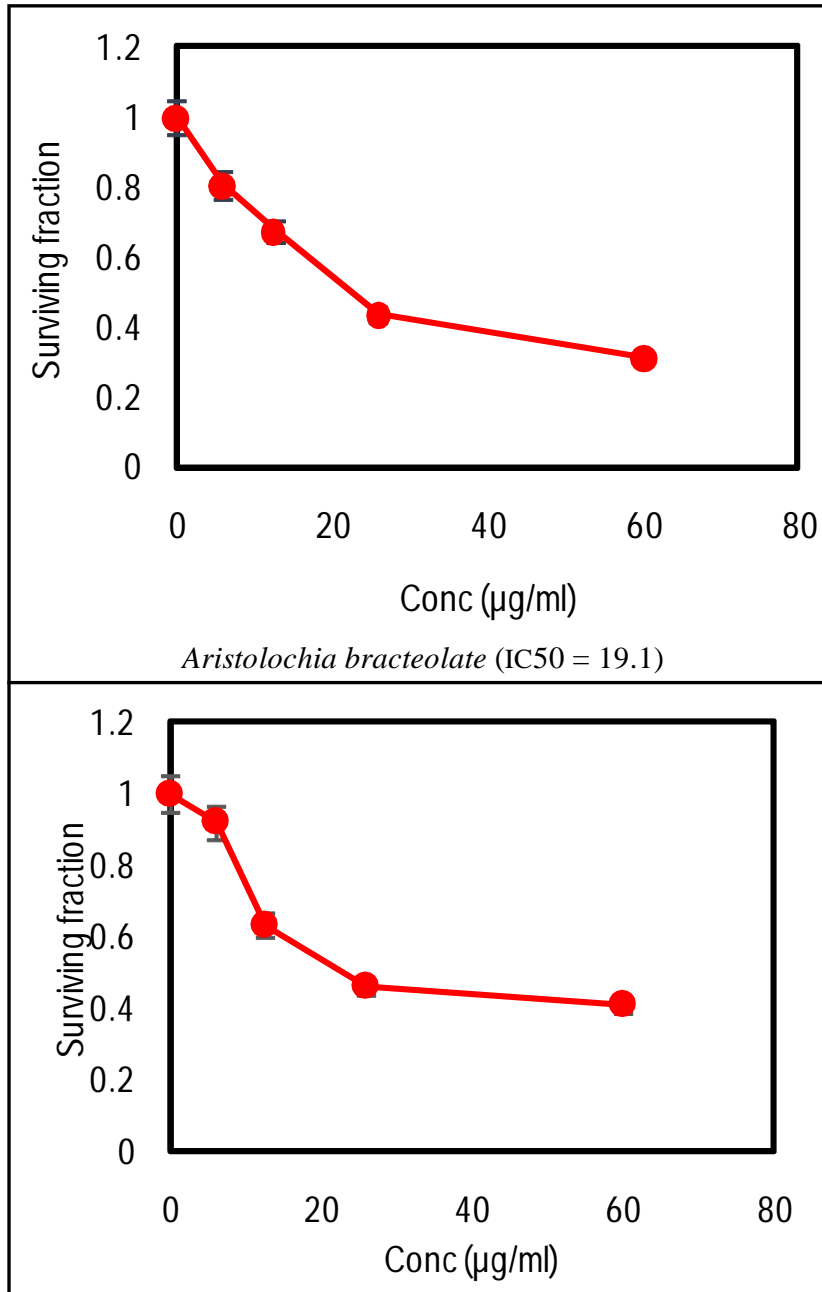

Brassica oleracea $(\mathrm{IC50}=21.7)$

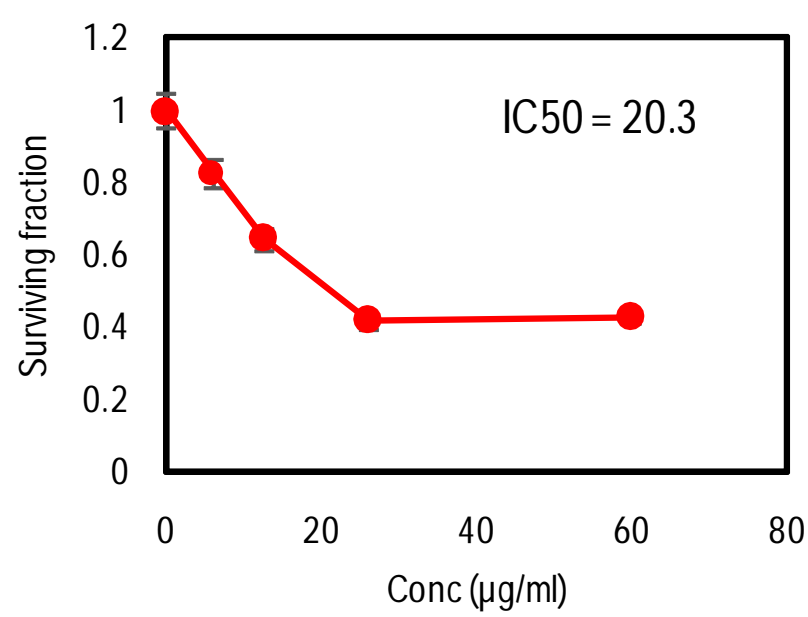

Capparis decidua $(\mathrm{IC50}=20.3)$ 


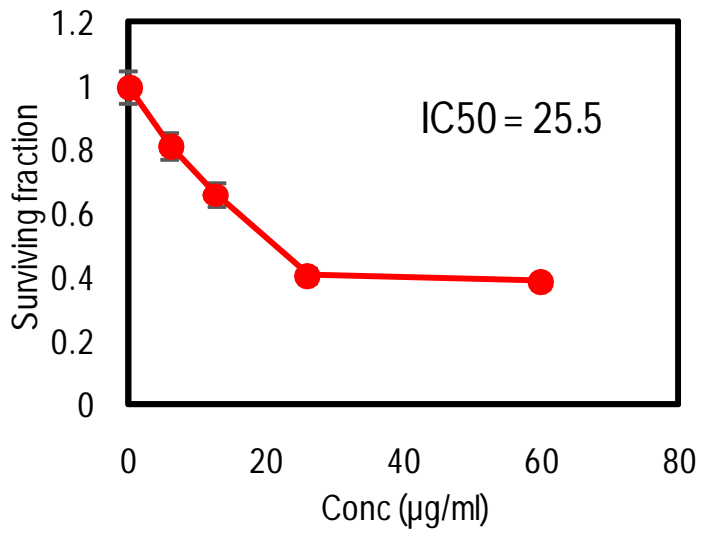

Cymbopogon citratus $($ IC50 $=25.5)$

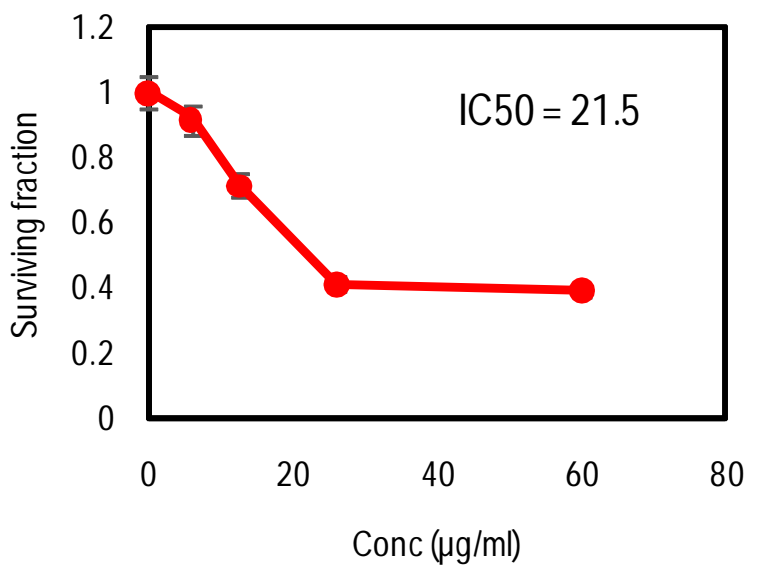

Grewia villosa $($ IC50 $=21.5)$

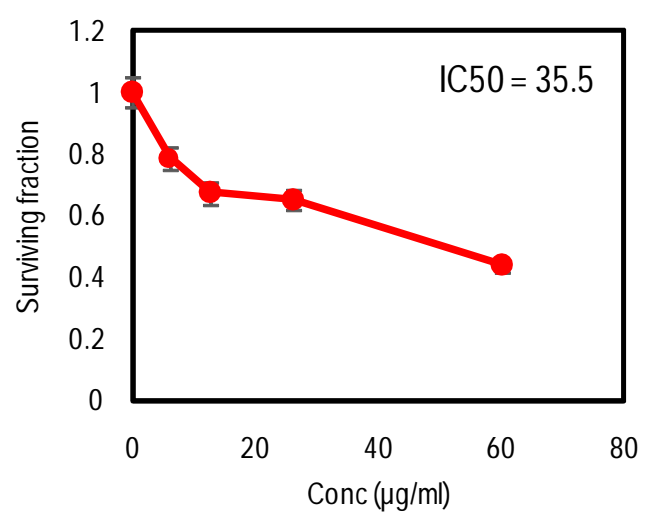

Hydnora abysinica $(\mathrm{IC50}=35.5)$

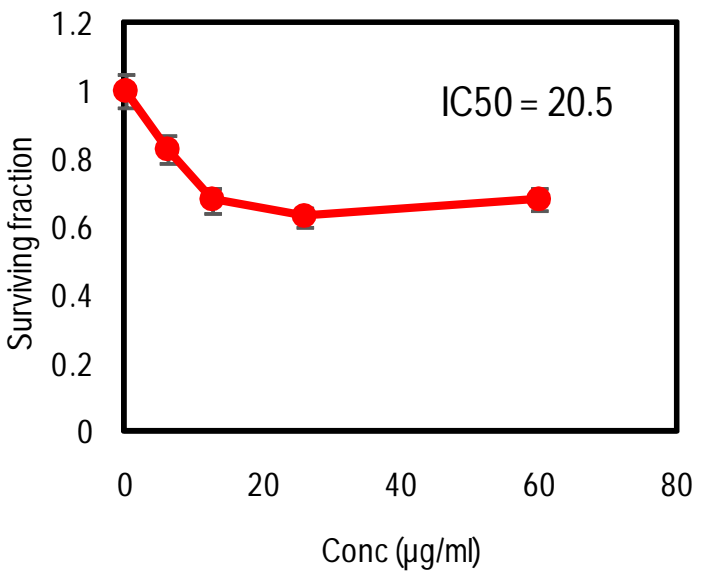

Lantana camara $($ IC50 $=20.5)$

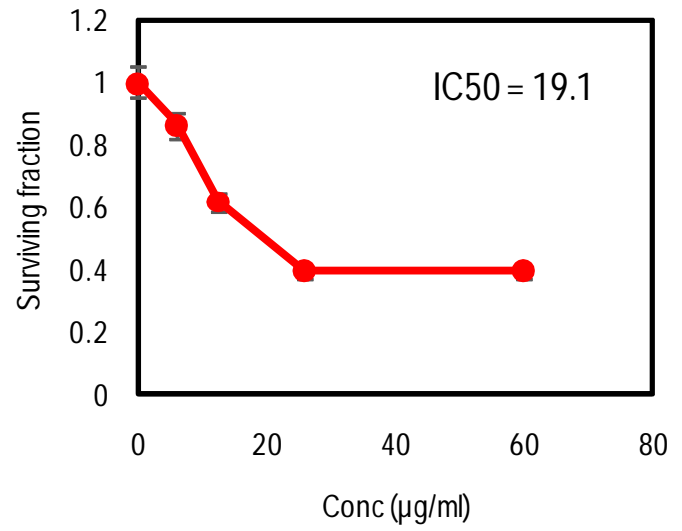

Lawsonia inermis $($ IC50 $=19.1)$

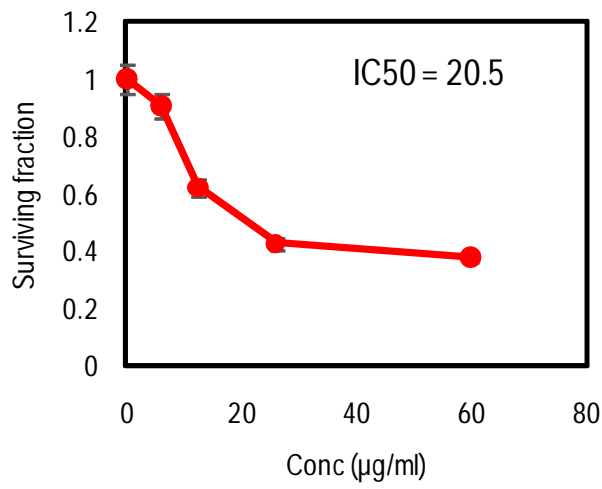

Trigonellafoenum-graecum $($ IC50 $=20.5)$ 


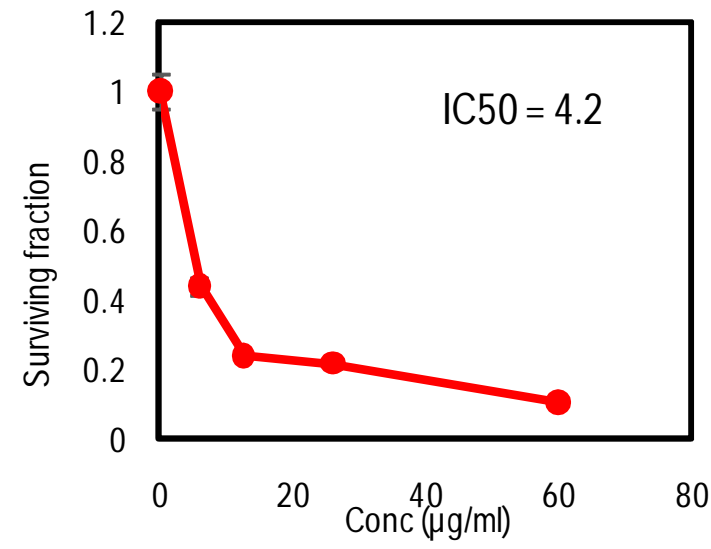

Doxorubicin (positive control) $\quad($ IC50 = 4.2)

Figure 1: $\mathrm{IC}_{50}$ for of selected plants and standard doxorubicin on MCF7 cell line.

Lantana camara showed high antioxidant activity using DPPH method and iron chelating assay. Additionally, this extract exhibited strong anti-breast cancer activity against MCF7 cell line. The presence of polyphenolic compounds, such as flavonoids, contributed to its antioxidant activity while anti-breast cancer activity might be due to the presence of polyphenolics, sterols and alkaloids (Iqbal et al., 2017; Lu et al., 2012; Bradford and Awad, 2007; Novotny et al., 2017).

Aristolochia bracteolate showed pronounced anticancer activity against MCF7 cell line and antioxidant activity using iron-chelating assay. However, the free radical scavenging activity using DPPH radical scavenging assay was only moderate, contrary to a previous study, showing the significant antioxidant activity of ethanolic exract of Aristolochia bracteolate using DPPH radical scavenging assay (Eltayeb and Nari, 2017). The potential antioxidant and anticancer activity of this plant might be due to the presence of phytochemicals such as flavonoids, sterols, alkaloids and saponins, which has been reported to play a significant role in inhibiting cancer cell activating proteins, enzymes and signaling pathways (Iqbal et al., 2017). Several studies have described the antioxidant and anticancer activity of Aristolochia species (Subramaniyan et al., 2015; Dirar et al., 2014).

Capparis deciduas (arial parts) and Trigonella foenum-graecum (seeds) have pronounced antioxidant activity using iron-chelating assay while their activities on scavenging DPPH radicals appeared to be low when compared with other plants. In the current study, Capparis decidua and Trigonella foenum-graecum exhibited anticancer activity against breast cancer (MCF-7) cells, which could be due to their antioxidant activities. These findings are in agreement with a study in India, where Capparis spinosa inhibited proliferation of hepatic (HepG2) cells, colon (HT29) and breast cancer MCF-7 cells (Upadhyay, 2011). The anticancer property of Trigonella foenum-graecum seeds might be due to presence of diosgenin, a steroid saponin, which has been reported to inhibit cell growth and induce apoptosis in colon cancer cell line (Raju et al., 2004). Additionally, fenugreek exhibited selective toxicity against various cancer cells including breast, pancreatic and prostate cancer cell (Wani and Kumar, 2018).
Other plants such as Grewia villosa, Hydnora abyssinica, Cymbopogon citratus and Brassica oleracea showed good antioxidant potential but were not very effective against MCF-7 cells as evident by their higher $\mathrm{IC}_{50}$ values.

\section{Conclusion}

We, thereby conclude that plants such as Lawsonia innermis, Lantana camara, Aristolochia bracteolate, Trigonella foenumgraecum and Capparis decidua are the promising candidates for use as natural products based antioxidant and anti-breast cancer for human health. As it is a preliminary study, we recommend further studies on these plants to evaluate their potential in in vivo and clinical study.

\section{Conflict of interest}

The authors declare that no conflict of interest exists in the course of conducting this research. All authors had final decision regarding the manuscript and the decision to submit the findings for publication.

\section{References}

Ayeni, K.E. and Yahaya, S.A. (2010). Phytochemical screening of three medicinal plants Neem leaf (Azadirachta indica), Hibiscus leaf (Hibiscus rosasinensis) and spear grass leaf (Imperata cylindrical). Continental J. Pharmaceutical Sci., 4:47-50.

Bradford, P.G. and Awad, A.B. (2007). Phytosterols as anticancer compounds. Mol. Nutr. Food Res., 51:161-170.

Clarkson, P.M. and Thompson, H.S. (2000). Antioxidants: What role do they play in physical activity and health. J. Clin. Nutr., 72:637646.

Dinis, T.C.P.; Madeira, V.M.C. and Almeida, L.M. (1994). Action of phenolic derivates (acetoaminophen, salycilate, and 5-aminosalycilate) as inhibitors of membrane lipid peroxidation and as peroxyl radical scavengers. Arch. Biochem. Biophys., 315:161-169.

Dirar, A.I.; Mohamed, M.A.; Osman, W.J.; Abdalgadir, H. and Khalid, H.S. (2014). A phytopharmacological review on four antitumor medicinal plants grown in sudan.. Am. J. Pharm.Tech. Res., 4:28-41.

Dyduch-Siemiñska, M.; Najda,A.; Dyduch, J.; Gantner, M. and Klimek, K. (2015). The content of secondary metabolites and antioxidant activity of wild strawberry fruit (Fragaria vesca L.). J. Anal. Methods Chem., 8(3): 12-38.

Eltayeb, I.M. and Nari, F.H.M. (2017). Phytochemical screening, antioxidant and antimicrobial activities of some Sudanese medicinal plants against standard and isolated microorganisms. J. Pharmacognos. Phytochem., 6:97-100.

Fabricant, D.S. and Farnsworth, N.R. (2001). The value of plants used in traditional medicine for drug discovery. Environ. Health Perspect, 109:69-75

Feher, J.; Csomos, G. and Vereckei, A. (1987). Free radical reactions in medicine. Berlin-Heidelberg, Springer-Verlag.,USA, pp:40-43.

Ferlay, J.; Soerjo mataram, I.; Ervik, M.; Dikshit, R.; Eser, S.; Mathers, C.; Rebelo, M.; Parkin, D.M.; Forman, D. and Bray, F. (2015). Cancer incidence and mortality worldwide: Sources, methods and major patterns in GLOBOCAN 2012. Int. J. Cancer., 136(5):359-386.

Gospodaryo, D. and Lushchak, V. (2012). Oxidative stress: Cause and consequence of diseases. In: Oxidative stress and diseases (ed. Lushchak VI, Gospodaryov DV) InTech. 
Guha, G.; Rajkumar, V.; Kumar, R.A. and Mathew, L. (2011). Antioxidant activity of Lawsonia inermis extracts inhibits chromium (VI) induced cellular and DNA toxicity. Evid. Based Complement. Alternat. Med., pp:576-656.

Hanahan, D. and Weinberg, R.A. (2000). The hallmarks of cancer. Cell, 100:57-70.

Hsouna, A.B.; Trigui, M.; Culioli, G.; Blache, Y. and Jaoua, S. (2011). Antioxidant constituents from Lawsonia inermis leaves: Isolation, structure elucidation and antioxidative capacity. Food Chem., 125:193-200.

Iqbal, J.; Abbasi, B.A.; Mahmood, T.; Kanwal, S.; Ali, B. and Khalil, A.T. (2017) Plant-derived anticancer agents: A green anticancer approach. Asian Pac. J. Trop. Biomed., 7:1129-1150.

Jackson, R.L.; George, K.U. and Thomas, C.E. (1993). Antioxidants: A biological defence mechanism for the prevention of atherosclerosis. Med. Res. Rev., 13:161-182.

Kattappagari, K.K.; Teja, C.S.R.; Kommalapati, R.K.; Poosarla, C.; Gontu, S.R. and Reddy, B.V.R. (2015). Role of antioxidants in facilitating the body functions: A review. J. Orofacial Sci., 7:71-75.

Kumar, S.; Sandhir, R. and Ojha, S. (2014). Evaluation of antioxidant activity and total phenol in different varieties of Lantana camara leaves. BMC Res. Notes., 22:560

Lim, J. and Luderer, U. (2011). Oxidative damage increases and antioxidant gene expression decreases with ageing in the mouse ovary. Biol. Reprod., 84(4):775-782.

Lu, J.J.; Bao, J.L.; Chen, X.P.; Huang, M. and Wang, Y.T. (2012). Alkaloids Isolated from natural herbs as the anticancer agents. Evid. Based Complement. Alternat. Med., pp:485-542.

Milivojeviæ, J.; Maksimoviæ, V.; Nikoliæ, M.; Bogdanoviæ, J.; Maletiæ, R. and Milatoviæ, D. (2011). Chemical and antioxidant properties of cultivated and wild fragaria and rubus berries. J. Food Quality, 34:1-9.

Mohammed, E.A.; Alagib, A. and Babiker, A.I. (2013). Incidents of cancer in Sudan: Past trends and future forecasts. Afr. J. Math., 8:136-142.

Morgan, G; Ward, R. and Barton, M. (2004). The contribution of cytotoxic chemotherapy to 5-year survival in adult malignancies. Clin. Oncol., 16:549-560.

Musa, M.S.; Abdelrasool, F.E.; Elsheikh, E.A.; Ahmed, L.A.M.N.; Mahmoud,A.L.E. and Yagi, S.M. (2011). Ethnobotanical study of medicinal plants in the Blue Nile State, South-eastern Sudan. J. Med. Plants Res. 5:4287-4297

Nagababu, E. and Lakshmaiah, N. (1992). Inhibitory effect of eugenol on non-enzymatic lipid peroxidation in rat liver mitochondria. Biochem. Pharmaco., 43:2393-2400.

Novotny, L.; Abdel-Hamid, M.E. and Hunakova, L. (2017). Anticancer potential of $\beta$-sitosterol. Int. J. Clin. Pharmacol. Pharmacother., 2:129.

Omar, B.; Mccord, J. and Downey, J. (1991). Ischaemia reperfusion. In Oxidative stress: Oxidants and antioxidants, (ed. Sies H), London: Academic Press, pp:493-527.

Phaniendra, A.; Jestadi, D.B. and Periyasamy, L. (2015). Free radicals: Properties, sources, targets, and their implication in various diseases. Indian J. Clin. Biochem., 30:11-26.

Rafieian-Kopaei, M.; Hosseini, M.; Shirzad, H. (2014). Comment on: Effect of pomegranate flower extract on cisplatin-induced nephrotoxicity in rats. J. Nephropathol., 3:121-123.
Raju, J.; Patlolla, J.M.; Swamy, M.V.; Rao, C.V. (2004). Diosgenin, a steroid saponin of Trigonella foenum-graecum (Fenugreek), inhibits azoxymethane-induced aberrant crypt foci formation in F344 rats and induces apoptosis in HT-29 human colon cancer cells. Cancer Epidemiol. Biomarkers Prev., 13:1392-1398.

Reynaert, N.L.; Ckless, K.; Guala,A.S.; Wouters, E.F.; van derVliet, A. and JanssenHeininger, Y.M. (2006). In situ detection of S-glutathionylated proteins following glutaredoxin-1 catalyzed cysteine derivatization. Bio.Chim. Biophys. Acta., 1760:380-387.

Seca, A.M.L. and Pinto, D.C.G.A. (2018). Plant secondary metabolites as anticancer agents: Successes in clinical trials and therapeutic application. Int. J. Mol. Sci., 19:263.

Shirzad, H.; Burton, R.C.; Smart, Y.C.; Rafieian-Kopaei, M. and Shirzad, M. (2011). Natural cytotoxicity of $\mathrm{NC}-2(+)$ cells against the growth and metastasis of WEHI-164 fibrosarcoma. Scand. J. Immunol., 73:8590 .

Shimada, K.; Fujikawa, K.; Yahara, K. and Nakamura, T. (1992). Antioxidative properties of xanthan on the antioxidation of soybean oil in cyclodextrin emulsion. J. Agric. Food Chem., 40:945-948.

Simonian, N.A. and Coyle, J.T. (1996). Oxidative stress in neurodegenerative diseases. Ann. Rev. Pharmacol.Toxicol., 36:83-106.

Skehan, P.; Storeng,R.;Scudiero, D.; Monks, A.; McMahon, J.; Vistica, D.; Warren, J.T.; Bokesch, H.; Kenney, S. and Boyd, M.R. (1990). New colorometric cytotoxicity assay for anticancer drug screening.J. Natl. Can. Inst., 82:1107-1112.

Smith, M.T. (1985). Role of reactive oxygen species and lipid peroxidation in chemically induced toxicity and carcinogenesis. In: Reactive oxygen species in chemistry, biology, and medicine (ed. Quintanilha A) New York: Plenum Press.

Society, American Cancer (2015). http://www.cancer.org/acs/groups/ content/@editorial/document/document/ acspc-044552.pdf. Cancer Facts and Figures. [Online] Atlanta,Ga.

Sugawara, H.; Tobis, K.; Minami, H.; Uekita, K.; Yoshie, H. and Onodera, S. (1992). Diabetes mellitus and reperfusion injury increase the level of active oxygen-induced lipid peroxidation in rat cardiac membranes. J. Clin. Exp. Med., 63:237-238.

Subramaniyan, V.; Saravanan, R.; Baskaran, D. and Ramalalingam, S. (2015). In vitro free radical scavenging and anticancer potential of Aristolochia indica L. against MCF-7 cell line. 6. Int. J. Pharm. Pharm. Sci., 7:392-396.

Sylvie, D.D.; Anatole, P.C.; Cabra, B.P. and Veronique, B.P. (2014). Comparison of antioxidant properties of extracts from three plants used for medical purpose in Cameroon: Acalypha racemosa, Garcinia lucida and Hymenocardia lyrata. Asian Pac. J. Trop. Biomed., S625-S632.

Tringali, C. (2001). Bioactive compounds from natural sources: Isolation, characterisation and biological properties. Taylor and Francis, London, pp:337-377.

Upadhyay, R.K. (2011). Kareel plant: A natural source of medicines and nutrients. Int. J. Green Pharm., 5:255-265.

Wani, S.A. and Kumar, P. (2018). Fenugreek: A review on its nutraceutical properties and utilization in various food products. J. Saudi Society Agricultural Sci., 17:97-106.

Young, I,. and Woodside, J. (2001). Antioxidant in health and disease. J. Clin. Pathol., 54(3):176-186.

Citation: Mazen Taha, Bushra Parveen, Bashier Osman, Iman H. Abdoon, Mona S. Mohamed, Wadah J.A. Osman and Sayeed Ahmad (2019). In vitro profiling of plants used in Sudanese traditional medicine for antioxidant and anti-breast cancer activities. Ann. Phytomed., 8(1):119-126. 